\title{
Archieve Media Promotion for Collective Memory Safety on Digital Natives Generations
}

\section{Media Promosi Arsip Untuk Penyelamatan Memori Kolektif Pada Generasi Digital Natives}

Paper Type:

Tinjauan Pustaka

Submitted 07 June 2019

Accepted 03 May 2019

Online 30 September 2019

* Correspondence: Rom Ubaidillah Muhammad

$$
\text { E-mail: }
$$

rom.ubaidillah.m@gmail.com

\section{Abstract}

Background of the study: Archives as a collective memory of a nation make it important to be managed and disseminated to all Indonesian people, especially in the current generation of Indonesian youth, namely the generation of digital natives. The generation of young people being the successors of the Indonesian nation's struggle must know the long history of the social history of the people in Indonesia through archives. The government has made a solution through a conscious archive movement but in reality the conscious socialization of the archives seems to not be heard in the community especially by the generation of digital natives. Access to archives carried out domestically in ANRI's annual report in 2015-2016 shows that in 2015 there were 5,215 people and in 2016 there were 4,747, a decline in 2016 regarding access to archives.

Purpose: This study aims to provide recommendations regarding the use of promotional media that can be carried out by ANRI institutions in maintaining the nation's collective memory, especially towards the generation of digital natives.

Method: This paper uses a literature review method with data collection of various materials contained in the library, such as newspapers, books, magazines, manuscripts, documents and so on that are relevant to research with theoretical studies and literature.

Findings: The results of this study indicate that the promotional media that is right for use by ANRI in promoting archives is through social media and media mobile phone applications based on the way of interaction of the generation of digital natives.

Conclusion: With this research, it is expected that ANRI as the highest institution managing state archives can consider the importance of promotion for archives and utilizing promotional media for the general public, especially in the generation of digital natives

Keywords: Archive, promotion media, rescue, collective memory, digital natives. 


\begin{abstract}
Abstrak
Latar Belakang Masalah: Arsip sebagai suatu memori kolektif suatu bangsa menjadikannya penting untuk dikelola dan disebarkan kepada seluruh masyarakat Indonesia, terutama pada Generasi anak muda Indonesia saat ini yaitu generasi digital native. Generasi anak muda menjadi penerus perjuangan bangsa Indonesia haruslah mengetahui perjungan panjang tentang sejarah sosial kebudayaan masyarakat di Indonesia melalui promosi arsip. Pemerintah sudah membuat solusi lewat gerakan sadar arsip namun pada kenyataan sosialisasi sadar arsip seakan tidak terdengar di masyarakat apalagi oleh generasi digital natives. Akses terhadap arsip yang dilakukan di dalam negeri pada laporan tahunan ANRI pada tahun 20152016 menunjukan angka pada tahun 2015 sebanyak 5.215 orang dan pada tahun 2016 sebanyak 4.747, terjadi penurunan pada tahun 2016 tentang akses terhadap arsip.
\end{abstract}

Tujuan: Penelitian ini bertujuan memberikan rekomendasi terkait pemanfaatan media promosi yang dapat dilakukan oleh lembaga ANRI dalam menjaga memori kolektif bangsa terutama terhadap generasi digital natives.

Metode: Tulisan ini menggunakan metode kajian pustaka dengan pengumpulan data bermacam-macam material yang terdapat diruang kepustakaan, seperti koran, buku-buku, majalah, naskah, dokumen dan sebagainya yang relevan dengan penelitian dengan kajian teoritis dan kepustakaan.

Hasil: Hasil dari penelitian ini menunjukan bahwa media promosi yang tepat digunakan oleh ANRI dalam melakukan promosi arsip adalah melalui sosial media dan media aplikasi mobile phone berdasarkan pada cara interaksi dari generasi digital natives.

Kesimpulan: Dengan penelitian ini diharapkan ANRI sebagai lembaga tertinggi pengelola Arsip negara dapat mempertimbangkan pentingnya promosi bagi arsip dan memanfaatkan media promosi bagi masyarakat umum terutama pada generasi digital natives.

Kata Kunci: Arsip, media promosi, penyelamatan, memori kolektif, digital natives.

To cite this document:

Muhammad, R.U., Anwary, A. (2019). Archieve media promotion for collective memory safety on digital natives generations. Record and Library Journal, 5 (1), 50 - 61. 


\section{Pendahuluan}

Arsip memiliki nilai sejarah didalamnya yang menjadi penting untuk dikelola dan disimpan. Menurut Jacobsen, punzalan, hedstrom (2013) arsip sering dicirikan sebagai institusi penting dari memori sosial kegiatan nya di anggap sebagai bentuk dari pelestarian memori. Seperti dalam konteks arsip negara, arsip memiliki nilai sejarah bangsa dan negara yang penting untuk dikelola dan disimpan sebagai bentuk memori kolektif bangsa. Memori kolektif disini memiliki makna nilai sejarah yang harus diketahui dan bisa diakses oleh semua orang agar menjadi pembelajaran bagi semua orang sebagai anggota masyarakat negara tersebut. Didalam konteks di Indonesia pengelolaan arsip terkait memori kolektif bangsa dijelaskan pada undang-undang nomor 43 tahun 2009; memori kolektif sebuah bangsa adalah sebuah jejak rekam dari sejarah perjalanan suatu bangsa yang perlu di abadikan sekaligus juga merupakan aset nasional yang menggambarkan identitas dan jati diri bangsa Indonesia yang sesungguhnya. Setiap langkah dan dinamika gerak maju bangsa, masyarakat, dan negara Indonesia ke depan harus didasarkan pada pemahaman, penghayatan, dan catatan atas identitas dan jati diri bangsa tersebut yang terekam dalam bentuk arsip. Arsip merupakan sebuah gambaran dari nilai adiluhur untuk kehidupan berbangsa dan bertanah air.

Konsep memori menempatkan bidang arsip dalam sesuatu yang lebih besar yang menjadi warisan dan budaya bahwa arsip adalah fondasi dari sumber ingatan (Jacobsen, Punzalan, Hedstrom: 2013). Namun mengelola dan menjaga nilai memori kolektif dalam arsip negara agar terus bermanfaat dan menjadi pembelajaran bersama dibutuhkan sosialisasi sadar arsip didalamnya. Sebagaimana yang dijelaskan undang-undang nomor 43 tahun 2009 Bab 9 pasal 36 ayat 2 bagian kesembilan tentang sosialisasi yaitu; 1) Lembaga kearsipan menggiatkan sosialisasi kearsipan sebagaimana dimaksud dalam Pasal 7 huruf h dalam mewujudkan masyarakat sadar arsip. 2) Sosialisasi kearsipan sebagaimana dimaksud pada ayat 1 dilakukan melalui pendidikan, pelatihan, bimbingan, dan penyuluhan serta melalui penggunaan berbagai sarana media komunikasi dan informasi. 3) Sosialisasi kearsipan sebagaimana dimaksud pada ayat 1 ditujukan pada lembaga negara, pemerintahan daerah, lembaga pendidikan, perusahaan, organisasi politik, organisasi kemasyarakatan, dan perseorangan. 4) Lembaga kearsipan menyediakan layanan informasi arsip, konsultasi, dan bimbingan bagi pengelolaan arsip masyarakat. Dari undang-undang nomor 43 tahun 2009 pasal 36 tersebut terdapat poin sosialisasi harus ditujukan kemasyarakat luas serta perseorangan dan dalam mensosialisasi arsip juga menggunakan sarana media komunikasi dan informasi. Bagaimana dengan implementasi yang sudah dilakukan ANRI terhadap penerapan Undang-undang terkait kegiatan sosialiasi arsip terhadap masyarakat. Berikut dijelaskan mengenai kegaitan ANRI selama tahun 2016-2017.

Tabel 1.Agenda ANRI Tahun 2016-2017 Berkaitan Tentang Sosialisasi Arsip

\begin{tabular}{lc}
\hline Sosialisasi Arsip ANRI & Tahun \\
\hline Kenalkan kesadaran arsip lebih dini, forum apresiasi kearsipan pada masyarakat & $27-7-2017$ \\
Diklat dasar dasar kearsipan & $10-04-2017$ \\
Kegiatan koordinasi digitalisasi arsip warisan budaya. & $05-04-2017$ \\
& \\
Wawancara Kepala ANRI dengan Majalah Trias Politika & $27-03-2017$ \\
Kunjungan SMKN 1 Brebes & $22-02-2017$ \\
Kunjungan Dinas Arsip Kota Blitar & $22-02-2017$ \\
Kunjungan DPRD Kabupaten Wonosobo & $22-02-2017$ \\
Sosialisasi Kebijakan Kearsipan untuk Pimpinan di Lingkungan Kementerian & $12-01-2017$ \\
kesehatan & \\
Workshop Penyelamatan Arsip Kepresidenan & $08-12-2016$ \\
Pameran Arsip Hubungan Sosial Budaya Indonesia - Tiongkok di Museum & $02-12-2016$ \\
Nasional, Jakarta & \\
Workshop Penyelamatan Arsip Pemilu & $22-08-2016$ \\
Pameran Arsip di Sarinah Plaza Jakarta & $23-08-2016$ \\
\hline
\end{tabular}

To cite this document:

Muhammad, R.U., Anwary, A. (2019). Archieve media promotion for collective memory safety on digital natives generations. Record and Library Journal, 5(1), 50 - 61. 
Dari data diatas menunjukan apa yang dilakukan oleh ANRI dalam kurun waktu tahun 20162017 terkait sosialisasi sadar arsip ANRI kepada masyarakat. Dapat diketahui bahwa media yang digunakan dalam melakukan sosialisasi arsip melalui diklat, kunjungan ke sekolah dan dinas arsip daerah, workshop, serta pameran arsip. Kegiatan sosialisasi yang dilakukan ANRI tersebut menimbulkan pertanyaan apakah media sosialisasi yang dilakukan ANRI tersebut sudah bisa merangkul semua lapisan masyarakat yang ada dan secara luas. Lalu bagaimana dengan sosialisasi arsip terhadap generasi digital natives yang menjadi generasi muda saat ini. Terkait dengan tingkat kunjungan masyarakat ke lembaga arsip diterangkan dalam laporan kinerja tahun 2016. ANRI memberikan akses kepada masyarakat umum, mahasiswa dan pelajar, instansi pemerintah pusat dan daerah, instansi swasta, kepolisian dan LSM yang membutuhkan arsip statis tersebut diatas untuk keperluan kegiatan pemerintahan, penelitian dan lain-lain. Dibawah ini adalah data kunjungan pertahun oleh masyarakat di seluruh Indonesia untuk mengakses arsip yang ada di ANRI.

Tabel 2. Penggunaan Arsip Terhadap Masyarakat Umum

\begin{tabular}{lllll}
\hline No & Tahun & $\begin{array}{l}\text { Pengguna } \\
\text { dalam negeri }\end{array}$ & Pengguna luar negeri & Jumlah \\
\hline 1 & 2015 & 4894 orang & 321 orang & 5215 orang \\
2 & 2016 & 4492 orang & 255 orang & 4747 orang \\
\hline
\end{tabular}

Sumber: Laporan Kinerja Tahunan ANRI 2016

Dari tabel diatas menjelaskan bahwa jumlah pengguna akses arsip dari luar negeri dan dalam negeri pada tahun 2015 dan tahun 2016 dengan total pengguna 9386. Terjadi penurunan jumlah pengguna arsip dari tahun 2015 ke tahun 2016. Jumlah pengunjung dalam negeri pada tahun 2015 dan 2016 sangat sedikit bila dibandingkan dengan jumlah penduduk indonesia, pada tahun 2016 misalnya pengunjung arsip dalam negeri tahun 2016 berjumlah 4.492 orang sedangkan penduduk Indonesia tahun 2016 berjumlah 257.912.349 orang dari data BPS (Badan Pusat Statistik). Data tersebut memberikan gambaran tentang sedikitnya akses pengguna arsip di Indonesia bahkan tidak mencapai $1 \%$ dari pendduduk Indonesia bila dibandingkan dengan jumlah masyarakat di Indonesia. Sedikitnya akses tersebut memiliki banyak faktor penyebab yang salah satunya adalah lemahnya sosialisasi arsip yang dilakukan oleh ANRI. Sebagaimana terlihat dari agenda ANRI selama tahun 2016-2017 terkait kegiatan sosialiasi arsip yang hanya menggunakan media berupa kegiatan, sosialisasi, workshop, pameran, dan kunjungan ke sekolah dan dinas-dinas arsip daerah.

Oleh karena itu permasalahan pada penelitian adalah, berdasarkan pernyataan diatas penulis menganggap kegiatan sosialisasi tidak akan bisa memberikan dampak yang cukup signifikan terhadap menjaga nilai kolektif bangsa, karena kegiatan sosialisasi hanya pada memberikan penanaman nilai dan memberikan informasi tanpa ada proses persuasif dan membangun image lembaga secara signifikan. Dalam hal ini penulis memberikan cara yang tepat untuk membranding arsip dengan menggunakan teori promosi dalam mengenalkan memori kolektif negara terhadap masyarakat luas. Promosi bisa membangun sebuah branding sebuah organisasi/lembaga didalam masyarakat. Promosi bisa digunakan dalam berbagai jenis kegiatan lembaga. Seperti lembaga arsip yang bergerak dalam bidang penyimpanan dan akses terhadap informasi publik. Promosi memiliki beberapa fungsi seperti fungsi promosi yang dijelaskan menurut Menurut Cannot, Perreault dkk (2009) yaitu; Informing (memberikan informasi), Persuading (membujuk), dan Reminding (mengingatkan).

Didalam proses promosi arsip tentu membutuhkan media sebagai alat dalam melakukan proses promosi. Perubahan mediapun sudah sangat berkembang pesat. Munculnya media baru dapat merangkul dan menyebarkan informasi secara cepat dan tepat keberbagai target pasar yang kita inginkan. Media baru yaitu media yang terhubung didalam jaringan komputer dan terhubung di internet akan lebih efektif dalam menyasar masyarakat luas terutama juga masyarakat digital natives. Digital natives (GenY) 
merupakan istilah yang merujuk pada generasi yang lahir pada tahun 1981-1995. Pada saat ini kisaran umur era digital natives adalah pada usia 23 Tahun sampai 37 Tahun. Dengan asumsi Digital Natives sebagai generasi yang menggambarkan generasi saat ini dan memiliki peranan penting dalam menjaga dan memilihara arsip sebagai tonggak sejarah bangsa. Fokus kajian penelitian ini adalah ingin memberikan rekomendasi media promosi yang tepat digunakan untuk generasi digital natives, dalam melakukan promosi terhadap arsip yang memiliki nilai memori kolektif bangsa.

\section{Tinjauan Pustaka}

Metode yang digunakan dalam tulisan ini menggunakan metode studi pustaka. Menurut Studi pustaka, menurut Nazir (2013) teknik pengumpulan data dilakukan dengan menelaah dan membaca buku-buku, literatur-literatur, catatan-catatan, dan laporan-laporan yang ada hubungannya dengan masalah yang ingin dipecahkan studi ini berarti mengumpulkan bahan-bahan dari perpustakaan dan dokumen dokumen yang terkait. Menurut Sugiyono (2012), studi kepustakaan berkaitan dengan kajian teoritis dan referensi lain yang berkaitan dengan nilai, budaya dan norma yang berkembang pada situasi sosial yang diteliti, selain itu studi kepustakaan sangat penting dalam melakukan penelitian, hal ini dikarenakan penelitian tidak akan lepas dari literatur-literatur Ilmiah Sugiyono (2012). Untuk pembahasan dari tulisan ini penulis mengkaji dari teori-teori yang berkaitan untuk menjawab pertanyaan gagasan media promosi yang digunakan oleh digital natives untuk mempromosikan memori kolektif arsip.

\section{Pembahasan dan Diskusi}

Sebelum memasuki pada pembahasan media promosi untuk digital natives, pertama penulis akan membahas tentang definisi arsip terlebih dahulu. Menurut Pasal 1 ayat 2 UU Nomor 43 Tahun 2009 tentang kearsipan; Arsip merupakan rekaman kegiatan atau peristiwa dalam berbagai bentuk dan media sesuai dengan perkembangan teknologi informasi dan komunikasi yang dibuat dan diterima oleh lembaga negara, pemerintahan daerah, lembaga pendidikan, perusahaan, organisasi politik, organisasi kemasyarakatan, dan perseorangan dalam pelaksanaan kehidupan bermasyarakat, berbangsa, dan bernegara. Dalam pengelolaan arsip terdapat beberapa jenis pengelolaan yaitu personal arsip, arsip organisasi dan arsip kolektif bangsa. Personal archiving adalah cabang keilmuan dari istilah kearsipan, yang berfokus pada penyimpanan dan pengumpulan arsip secara perorangan (pribadi), dan juga pelestarian pada kertas dan dokumen pribadi lainnya umumnya dilakukan oleh pribadi yang bersangkutan. Personal archiving juga sering dikaitkan dengan dokumen sejarah keluarga yang disimpan, ketika individu merangkum sejarah kehidupannya sendiri untuk meninggalkan sebuah pengetahuan akan silsilah keluarga dan sebagai warisan bagi generasinya yang akan datang. Personal archiving juga termasuk format seperti foto, video dan macam macam kegiatan tentang individu dalam berbagai materi.

Kedua adalah arsip organisasi, organization archiving /business archiving menurut Glossary American Archivists adalah "Records created or received by a commercial enterprise in the course of operations and preserved for their enduring value. 1) Materials created or received by a person, family, or organization, public or private, in the conduct of their affairs and preserved because of the enduring value contained in the information they contain or as evidence of the functions and responsibilities of their creator, especially those materials maintained using the principles of provenance, original order, and collective control; permanent records. 2. The division within an organization responsible for maintaining the organization's records of enduring value. 3. An organization that collects the records of individuals, families, or other organizations; a collecting archives.4. The professional discipline of administering such collections and organizations". Arsip jenis ini adalah arsip milik suatu organisasi / perusahaan yang di dalamnya terdapat berbagai jenis kegiatan dan dokumen dari perusahaan berupa sejarah dan segala hal yang berkaitan organisasi tersebut. Arsip ini biasanya tidak terbuka untuk umum hanya untuk kalangan pekerja dan pengelola dari organisasi itu sendiri. Arsip jenis ini sangat peduli akan integritas perusahaan dan sangat selektif tentang material-material yang digunakan. Arsip organisasi 
menjalani perubahan dengan penanganan oleh dan melalui kebudayaan komunitas, pendiri dan penerus komunitas sangat dipandang dan dihormati (Ike, 2013). Dikatakan Ratih (2016) arsip sebagai sumber informasi memiliki banyak fungsi dalam penggunaannya di instansi/organisasi.

Arsip selain memiliki kegunaan dinamis (fungsi administrasi) arsip juga sebagai memori kolektif (fungsi statis), karena melalui arsip kolektif tersebut dapat tergambar perjalanan sejarah atau keberadaan negara dari masa ke masa. Arsip kolektif merupakan arsip yang berperanan penting dalam kegiatan yang berkaitan dengan peristiwa penting/bersejarah dan kesinambungan sebuah instansi. Senada dengan pidato kepala ANRI (2015) yang menyampaikan bahwa melalui arsip dapat tergambar perjalanan sejarah bangsa dari masa ke masa. Memori kolektif tersebut adalah juga identitas dan harkat sebuah bangsa. Kesadaran akan pentingnya arsip harus berlandaskan kepada sebuah tanggung jawab dan berorientasi akan warisan kepada generasi selanjutnya karena penyelamatan arsip sebagai pertanggung jawaban nasional sekaligus sebagai warisan budaya bangsa yang senantiasa harus dijaga dan dirawat keberlangsungan nya, dengan tujuan untuk menghindari kehilangan dari nilai informasi sejarah perjalanan bangsa. Memori kolektif ini harus disampaikan melalui kegiatan promosi, karena didalam promosi lebih bersifat membujuk, merayu, dan lebih bersifat persuasif. Seperti dijelaskan oleh Fandy (2018) mengemukakan bahwa promosi adalah suatu bentuk komunikasi pemasaran, yang di maksud dengan komunikasi pemasaran adalah aktivitas pemasaran yang berusaha menyebarkan informasi, mempengaruhi atau membujuk, dan mengingatkan pasar sasaran atas perusahaan dan produknya agar bersedia menerima, membeli, dan loyal pada produk yang ditawarkan perusahaan yang bersangkutan.

Untuk memperkuat dari argumen tentang teori promosi, dijelaskan oleh Cannot, Perreault dkk (2009) bahwa promosi memiliki tujuan sebagai berikut: 1) Menginformasikan produk jasa dan kegiatan yang dilakukan oleh suatu lembaga dan organisasi. 2) Membujuk; Selain menginformasikan kepada konsumen tentang produk yang dipasarkan, membujuk juga penting dalam promosi. Membujuk merupakan usaha untuk mendemonstrasikan mengapa suatu merek lebih baik dibandingkan dengan yang lainnya sehingga konsumen akan membeli, dan terus membeli produk yang dipasarkan. Membujuk adalah menjelaskan dengan gamblang kepada konsumen tentang produk jasa yang diberikan sehingga konsumen tertarik untuk memakai dan menggunakan produk. 3) Mengingatkan, Sebagai sarana untuk konsumen selalu mengunjungi dan memakai produk, produsen harus selalu mengingatkan bagaimana tentang kepuasaan ketika konsumen memakai dan menggunakan produk yang dipromosikan. Dalam mempromosikan sesuatu ada langkah-langkah program promosi yang bisa dilakukan oleh komunikator pada bidang pemasaran, yaitu: a) Mengindentifikasi pendengar atau pemirsa, b) Menentukan tujuan komunikasi, c) Merancang pesan, d) Mengalokasikan anggaran promosi, e) Merumuskan tentang bauran promosi, f) Mengukur hasil promosi g), Pengelola mengkoordinasikan proses komunikasi pemasaran secara keseluruhan. Langkah-langkah dalam melakukan promosi merupakan sesuatu yang terencana secara matang, pertama terkait mengidentifikasi pendengar dan pemirsa adalah salah satu penentuan sasaran dari target promosi yang akan dilakukan. Terkait dengan tulisan ini adalah mempunyai sasaran promosi terhadap digital natives. Kedua tentang media yang efektif digunakan sebagai media promosi merupakan sesuatu yang penting untuk dipikirkan.

Untuk mencapai sasaran promosi secara efektif dibutukan media didalamnya. Didalam kamus en.oxforddictionaries.com media diartikan sebagai sarana utama komunikasi massa (penyiaran, penerbitan, dan internet) dianggap secara kolektif. Dalam buku Medium is The Message (1967) McLuhan dalam Putu Laxman Pendit (2013) mengembangkan pengertian bahwa media dan teknologi adalah sama saja, dan bahwa media adalah perpanjangan atau perluasan (extension) dari manusia. Misalnya roda kendaraan adalah perpanjangan dari kaki manusia, buku adalah perluasan dari mata, pakaian adalah perpanjangan dari kulit manusia, sirkuit elektronik adalah perluasan dari urat syaraf manusia. Jadi semua artefak (buatan manusia) dilihat sebagai perpanjangan dari salah satu bagian tubuh manusia, kakinya, tangannya, atau jaringan syarafnya. Generasi digital natives pada dasarnya muncul ketika new media atau media yang terhubung melalui jaringan internet ini hadir. New media merupakan sebutan saat ini untuk media yang menggunakan jaringan internet, media online yang berbasis akan teknologi (Mondry, 2008). 
Generasi digital natives merupakan generasi yang tidak bisa lepas dari teknologi informasi. Generasi ini dikenalkan oleh Marc prensky yang menyebutkan bahwa generasi digital natives merupakan generasi yang dari awal kelahiran sudah mengenal teknologi digital disekitarnya dan dikesehariannya (Marc Prensky, 2001). Marc Prensky (2001) juga menyebutkan generasi digital native sudah lebih mandiri dalam pembelajaran dan memproses informasi karena kebiasannya dalam menggunakan teknologi secara intens setiap harinya. Senada dengan prensky, Selwyn (2009) menejelaskan, generasi digital natives adalah generasi yang fleksibel dan multitasking mereka bebas untuk memilih dengan siapa dan kapan saja mereka berinteraksi. Untuk mengetahui media yang tepat dalam promosi arsip akan lebih baik melihat dari cara interaksi dari digitial natives ini sendiri. Seperti yang dijelaskan oleh Gasser dan Pal-frey (2008) dalam Amelia Virginia (2012) menyebutkan cara interaksi dari digital natives adalah sebagai berikut: 1) Generasi ini berbeda. Mereka belajar, bekerja, me-nulis, dan berinteraksi dengan orang lain melalui cara yang berbeda dengan generasi sebelumnya. Mereka lebih memilih untuk membaca blog dibandingkan dengan surat kabar. 2) Mereka lebih memilih untuk bertemu orang lain secara online sebelum bertemu seccara langsung.3) Mereka mungkin tidak mengetahui bentuk kartu perpustakaan, meskipun memilikinya mereka mungkin tidak pernah menggunakannya.4) Mereka mendapatkan musik secara online seringkali secara gratis dan illegal, daripada membelinya di toko musik. 5) Mereka lebih suka mengirimkan instant message (IM) daripada mengangkat telepon dari teman untuk mengatur waktu pertemuan pada siang hari. 6) Mereka mengadopsi dan bermain dengan binatang peliharaan melalui They Virtual Neopets online dari pada bermain dengan hewan peliharaan sesungguhnya. 7) Mayoritas aspek kehidupan mereka -interaksi sosial, pertemanan, aktivitas kemasyarakatan dimediasi oleh teknologi digital. Mereka tidak pernah tahu kehidupan yang sesungguhnya.

Dari cara interaksi yang dilakukan oleh generasi digital natives diatas didapatkan beberapa pendekatan dari beberapa media yang digunakan oleh digital natives dalam berinteraksi dan mengakses informasi. Mereka banyak mengakses informasi dan berita melalui blog berita online. Kedua mereka lebih suka bersosialisasi melalui online, dalam hal ini menggunakan sosial media sebagai medianya, Ketiga mereka banyak mengunduh konten, musik, film dokumen dll secara gratis, Keempat mereka suka menggunakan instant massage daripada telepon dalam hal ini bisa menggunakan aplikasi whatsapp/line sebagai media chating populer di Indonesia. Mereka juga menyukai game/ permainan secara online daripada melakukan permainan secara langsung. Dari hasil identifikasi kemudian penulis menggunakan pendekatan beberapa konsep media yang dirasa sesuai dengan menggunakan analisis data-data tambahan yang mendukung.

\section{Sosial Media}

Sebelum membahas sosial media lebih mendalam penulis ingin memberikan data statistik dari https://databoks.katadata.co.id, yang menunjukkan pengguna internet di Indonesia. 


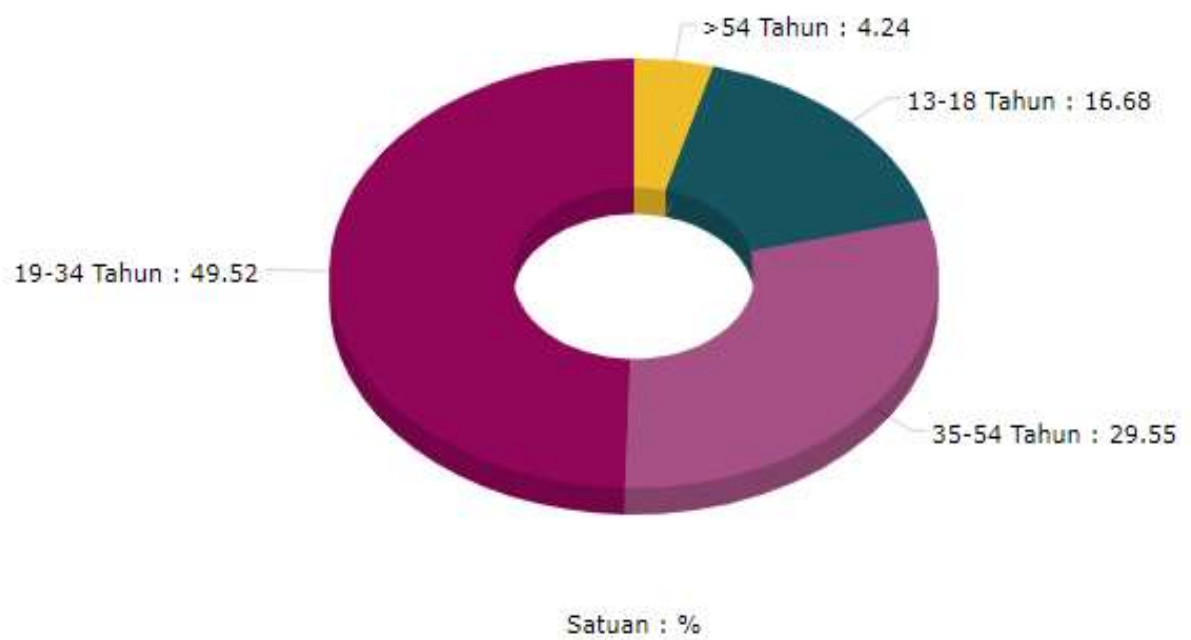

Grafik 1 Statistik Pengguna Internet Berdasarkan Kelompok Usia (Sumber. https://databoks.katadata.co.id)

Data tersebut menunjukkan bahwa pengguna akses pada tahun 2017 didominasi oleh umur 1934 tahun. Umur tersebut merupakan menunjukkan penggunaan dari generasi digital natives, dimana bila berpijak pada pendapat Marc Prensky (2001) digital natives merupakan generasi yang lahir pada tahun 1990 keatas. Secara hitung-hitungan digital natives pada tahun 2007 sudah berkisar umur 27 tahun kebawah. Digital natives cenderung mengakses media sosial secara aktif karena karakter mereka yang suka berkomunikasi secara sosial oleh karena itu media sosial merupakan salah satu media yang tepat bagi mereka. Media sosial merupakan salah satu media daring yang paling banyak digunakan oleh digital natives dalam bersosialisasi hal ini karena sifatnya yang mudah digunakan dalam berkomunikasi dimana saja asal bisa terhubung dengan Internet. Ada survei menarik tentang penggunaan media sosial di Indonesia pada mei 2018 yang dilakukan oleh statcounter menyebutkan bahwa urutan media sosial yang paling banyak digunakan di Indonesia pada bulan mei 2018 adalah Facebook, Youtube, Twitter, Pinterest Instagram dan Google+.

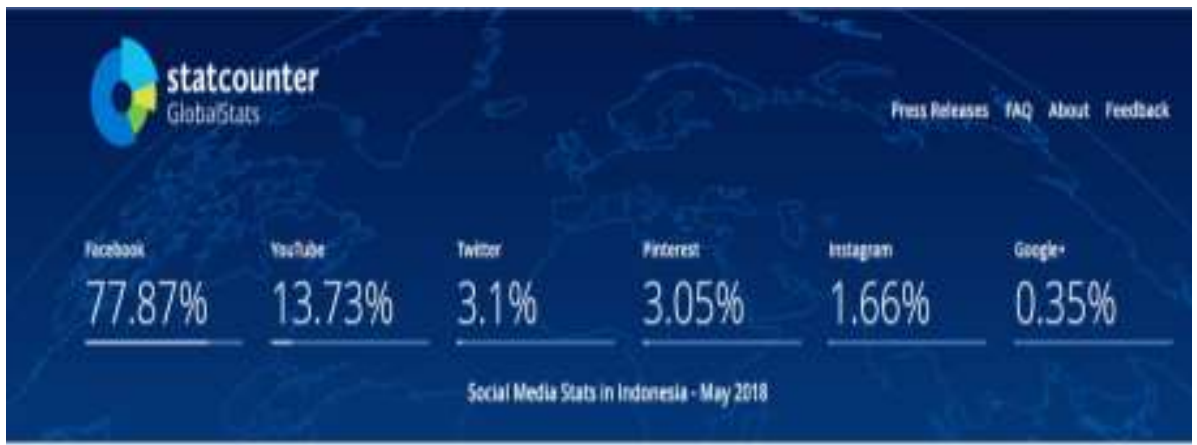

Grafik 2. Statistik Media Sosial di Indonesia Mei 2018 (Sumber:statcounter.com)

Statistik yang dirilis oleh stat counter menggambarkan bahwa media sosial di Indonesia masih didominasi oleh facebook, hal ini mungkin karena facebook muncul diawal sebelum media sosial yang lainnya. Untuk melihat kecenderungan digital natives menggunakan media sosial berikut akan disajikan data yang lebih spesifik oleh penelitian yang dilakukan oleh Pujasari Supratman (2018) yang meneliti tentang penggunaan media sosial pada mahasiswa Universitas Telkom Bandung dengan informan

To cite this document:

Muhammad, R.U., Anwary, A. (2019). Archieve media promotion for collective memory safety on digital natives generations. Record and Library Journal, 5(1), 50 - 61. 
generasi digital natives sebanyak 225 informan. Hasilnya adalah media sosial yang sering digunakan adalah pertama instagram, kedua line, ketiga youtube, keempat whatsapp,kelima facebook, keenam snapchat,ketujuh twitter, dan kedelaoanask.fm. Walaupun hanya dengan penelitian pada lingkup kecil, namun penelitian ini memberikan gambaran kecenderungan dari beberapa media sosial yang sering diakses oleh generasi digital natives. Beberapa media penelitian Pujasari Supratman (2018)yang digunakan tersebut saya kira bisa digunakan semua untuk promosi, namun beberapa media seperti instagram, youtube, facebook dan twitter lebih direkomendasikan.

Untuk lebih bisa membuat rencana promosi yang baik terhadap arsip dengan menggunakan media tersebut, sebaiknya perlu melihat dari kecenderungan alasan digital natives menggunakan media tersebut. Hasil penelitian Pujasari Supratman (2018) menggambarkan hasil dari alasan digital natives menggunakan media sosial instagram sebagai yang terfavorit; Instagram memiliki banyak fasilitas seperti, menyediakan posting edit foto snapgram (caption, filter, efek unik, dan stiker lucu), instastories, video pendek, bumerang, superzoom, rewind, handsfree dan slow motion, berita mutakhir, link informasi gosip dan akunmeme, video tutorial, dan klip karaoke yang membuat digital native dapat berlama-lama menikmati fitur fasilitas yang disediakan oleh instagram. Dengan menggunakan instagram juga mencermikan bahwa generasi digital natives mengikuti perkembangan zaman dan perubahan. Kedua youtube, alasan penggunaan adalah media audio visual pilihan digital natives untuk menonton film, acara TV yang terlewat, menonton video dan vlog. Kecendrungan digital natives yang lebih menyukai sesuatu secara visual menjadi pendorong mengapa perlu digalakan promosi arsip melalui youtube, lembaga arsip bisa berkolaborasi dengan youtuber terkenal untuk membuat konten tentang pentingnya arsip dan pengelolaannya di kalangan generasi digital natives, Ketiga whatsapp, whatsapp dipilih sebagai media audio visual pilihan digital natives sebagai media sosial yang paling mudah digunakan karena dapat langsung terhubung hanya dengan mengunakan telepon di aplikasi whatsapp penggunaan whatsapp dengan broadcast dan pesan berantai sering viral disemua kalangan inipun bisa digunakan oleh lembaga untuk membuat sebuah gagasan menyasar generasi digital natives melalui broadcast whatsapp. Keempat twitter, twitter menjadi rujukan berita dan informasi yang menjadi trending topic bagi digital natives ada perubahan tren bahwa apabila menginginkan berita yang cepat dengan menggunakan twitter, twitter dengan trenwords nya membuat hastag yang bisa memviralkan suatu kata,ini juga bisa dipakai untuk mempromosikan arsip dengan hastag hastag yang menarik untuk digunakan dan disebarkan luaskan. Setiap sosial media memiliki figur-figur yang terkenal yang diikuti jutaan followers ini menjadi sebuah acuan bagi lembaga arsip untuk bisa menggunakan pemilik akun-akun terkenal untuk berkolaborasi dan menjadikan mereka brand ambassador dari lembaga arsip untuk menarik dan menggangkat kembali bahwa penyelamatan memori kolektif dikalangan generasi digital natives penting. Dengan melihat alasan-alasan digital natives memanfaatkan media seperti Youtube, Instagram, Twitter, whatsapp dapat dijadikan celah bagi lembaga arsip dalam mempromosikan arsip melalui cara-cara yang disukai oleh digital natives. Sebagai contoh pengunaan media sosial youtube oleh digital natives adalah untuk menonton film, dan menonton vlog, lalu lembaga arsip bisa membuat sebuah film yang menarik atau video vlog yang menarik dengan konsep yang disukai oleh para digital natives dalam mempromosikan arsip kolektif bangsa. Begitu pula dengan media-media sosial lainnya seperti Instagram, Facebook, Twitter dan watshapp.

\section{Mobile Phone (M-Arsip)}

Mobile Phone dipilih sebagai media selanjutnya adalah karena kecenderungan orang mengakses informasi sekarang lebih banyak menggunakan akses dari mobile phone ketimbang laptop/tablet, kedua karena alasan generasi digital natives yang juga cenderung mengakses informasi dengan cara yang lebih praktis yaitu dengan menggunakan telepon genggam. Seperti statistik dibawah ini menyebutkan bahwa pengguna ponsel lebih banyak dari pada pengguna tablet dan desktop, terlihat dari survei yang dilakukan statcounter sebanyak 71,82\% pengguna internet di Indonesia pada bulan mei 2018 menggunakan mobile phone. 


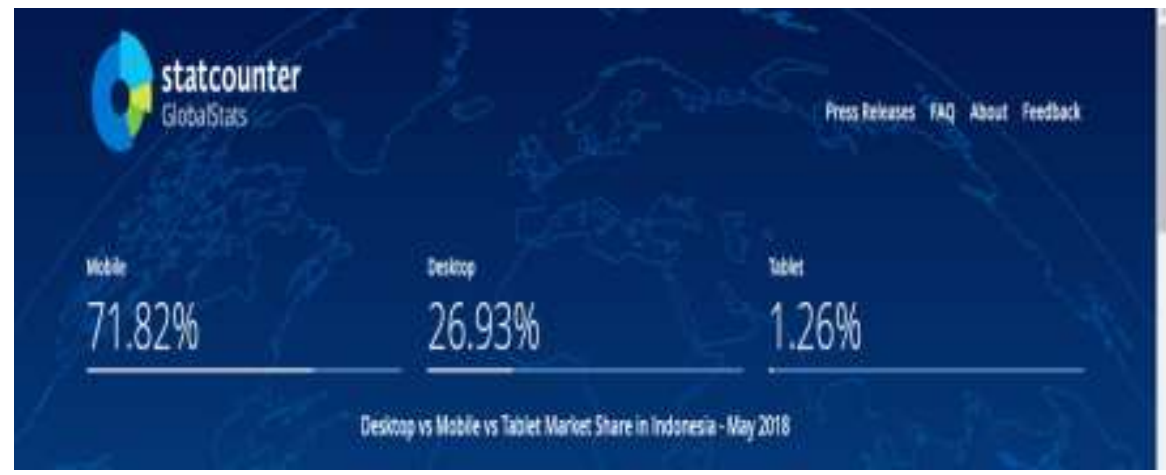

(Sumber: http://statcounter.com/)

Grafik 3. Statistik Perbandingan Pengguna Mobile, Dekstop dan Tablet di Indonesia

Promosi melalui mobile phone dalam mempromosikan arsip bisa dengan membuat sebuah aplikasi seperti m-library / i-pusnas dll, dengan konsep 2.0 yang bisa membuat para digital natives berinteraksi layaknya di media sosial. Aplikasi mobile untuk arsip / M-Arsip akan sangat membantu dikalangan digital natives untuk berinteraksi lebih dekat dengan informasi dari arsip yang diinginkannya, dalam perkembangan saat ini aplikasi untuk arsip hanya sebatas pada aplikasi pembuat dan penyedia layanan untuk arsip statis dan dinamis namun belum adanya aplikasi mobile untuk masyarakat membaca arsip dimana saja dan kapan saja. Dengan adanya M-arsip maka diharapkan kecenderungan dari akses terhadap arsip akan bernilai tinggi karena dalam proses akses akan menjadi lebih mudah dan bisa dilakukan dimana saja. M-arsip juga akan membantu segi pembelajaran dan pendidikan karena informasi kolektif suatu bangsa sudah berada hanya pada genggaman yaitu smartphone. Fitur-fitur didalam Marsip akan sangat membantu dalam pencarian informasi sejarah dengan tata kelola didalam yang baik. Seperti halnya I-pusnas yang dimiliki oleh perpustakaan nasional, didalam nya pengguna dapat berinteraksi antara pengguna secara langsung menjadikan keterhubungan di antara pemakai aplikasi, penelusuran akan koleksi yang dimiliki ANRI berdasarkan subjek, kategori dan hal lain nya relatif lebih mudah dan seperti M-library tentang komunikasi dengan pengelola akan terbangun. M-arsip yang berbentuk aplikasi yang didalamnya tersimpan database informasi tentang memori kolektif bangsa bisa sebagai ajang promosi kekinian yang membantu ANRI untuk promosi terhadap generasi digital natives, dialam sebuah $\mathrm{M}$-arsip terdapat bagan tahun ataupun abjat nama yang menunjukan sebuah urutan dari koleksi yang tersedia juga diharapkan didalam M-arsip terdapat informasi tambahan dengan format visual/gambar untuk memudahkan generasi digital natives untuk mempelajari keadaan sejarah pada masa tersebut ini juga akan membantu pembelajaran kognitif siswa disekolah kolaborasi dari Anri bisa ditujukan kepada sekolah dan dinas pendidikan untuk menunjang pembelajaran siswa, karena gaya belajar yang cepat dan dinamis dari digital natives dalam memproses informasi yang visual maka akan memudahkan (Mardina, 2011). Pembuatan mobile arsip perlu dipertimbangkan secara lebih lanjut dalam tahap pelayanan secara maksimal dan promosi tepat guna untuk digital natives.

\section{Simpulan}

Keberadaan arsip sebagai suatu memori kolektif bangsa kurang diperhatikan oleh pemerintah dan lembaga terkait. Hal ini terlihat dari data pengunjung arsip pada tahun 2015 dan 2016 didaapt dari laporan tahunan ANRI yang menunjukkan angka sangat kecil dibanding dengan jumlah populasi masyarakat Indonesia. Lebih jauh sosialisasi sadar arsip yang dilakukan hanya pada tingkat instansi dan staff pemerintah, sosialisasi belum berdampak kepada masyarakat yang lebih luas. Pemerintah perlu lebih luas untuk memperhatikan perkembangan dari keterpakaian arsip, apalagi generasi saat ini yang tersentuh dengan teknologi harus dilakukan cara yang lebih masif untuk generasi digital natives mengenal akan memori kolektif bangsa. Diperlukan cara yang tepat dan efektif dalam menyampaikan arsip kepada generasi digital natives, dengan melakukan serangkaian promosi yang berbeda melalui sosial media, dan mobile arsip bisa menjadi pilihan yang harus dipikirkan oleh pemerintah dan lembaga terkait. Diperlukan penelitian lebih lanjut tentang kearsipan terutama kepada perilaku pencari arsip dan 
apa yang sebenarnya dibutuhkan oleh para digital natives pada era saat ini dan yang akan datang, ini akan menjadi sebuah acuan dan tolak ukur bagaimana kerelevanan sebuah program promosi yang baik untuk dilakukan dan menjadi dasar dari pengambilan keputusan. Media akan selalu berkembang dengan kemajuan teknologi, promosi dan bauran pemasaran lain nya juga akan ikut tergerus mengikuti perkembangan tersebut. Untuk menghindari ketertinggalkan dan ditinggalkan maka pemerintah dan lembaga arsip terkait perlu berbenah diri dalam hal program yang harus dilakukan setiap tahunan nya dan media seperti apa yang diminati oleh digital natives pada saat ini. Tidak hanya pada medianya saja namun bagaimana teknik dan konten promosi yang bisa dimuat juga perlu dipikirkan bagi lembaga arsip dalam mempromosikan arsip kolektif bangsa.

\section{Referensi}

ANRI. (2017, Mei 5). Agenda ANRI. Retrieved form http://www.anri.go.id/category/2-186-Agenda/20. ANRI. (2016). Laporan Kinerja ANRI tahun 2016. Jakarta. Indonesia: ANRI.

ANRI. (2015, Mei 5). Sambutan Kepala Arsip Nasional Republik Indonesia Pada Acara Penyerahan Arsip Citra Daerah Kabupaten Gianyar. Retireved fromwww.anri.go .id/assets/.../serah_terima_citra_daerah_kab_gianyar568460614aa10.pdf.

ANRI. (2009). UU Nomor 43 Tahun 2009 Tentang Kearsipan. Jakarta, DKI: Pemerintah. Retrieved from https://www.anri.go.id/assets/.../87Nomor-43-Tahun-2009-Tentang-Kearsipan.pdf.

Barratt, N. (2010). Nick Barratt's beginner's guide to your ancestors' lives. Bransley, South Yorkshire: Pen \& Sword Family History.

Cannot., Josep P.P., William, D., \& McCarthy, E.J. (2009). Pemasaran Dasar Pendekatan Manajemen Global. Jakarta, Indonesia: Salemba 4.Fandy, T, (2008). Strategi Pemasaran, Yogyakarta, Indonesia: ANDI.

Jacobsen, T., Punzalan, R. L., \& Hedstrom, M. L. (2013). Invoking “collective memory": mapping the emergence of a concept in archival science. Archival Science : International Journal on Recorded Information, 13, 217-251.

Koentjaraningrat. (1983). Metode-Metode Penelitian Masyarakat. Jakarta, Indonesia: Gramedia.

Kotler, P. (1997). Manajemen Pemasaran. Surakarta, Indonesia: PT Pabelan.

Lawanda, I.I. (2013). Arsip Sebagai Memory Kolektif: Dipresentasikan di International Conference On Indonesian Studies (ICSS) Yogyakarta, new shapir hotel, 13-14 juni 2013 (pp. 257-264). Jalan Prof. Dr. Selo Soemardjan, Fakultas Ilmu Pengetahuan budaya Universitas Indonesia.

Mardina, R. (2011). Potensi digital natives dalam representasi literasi informasi multimedia berbasis web di perguruan tinggi. Jurnal pustakawan Indonesia vol 11 no 1 . Retireved from https://journal.ipb.ac.id/index.php/jpi/article/download/5264/3681.

Muhadi, M. (2015). Pengaruh Biaya Promosi Terhadap Omzet Penjualan Cheesecake Pada L'cheese Factory Pekanbaru Ditinjau Dalam Ekonomi Islam (Skripsi, 2015, Universitas SUSKA Riau). Retrieved from http://repository.uinsuska.ac.id/6661/.

Mondry. (2008). Pemahaman teori dan praktik jurnalistik. Bogor: Ghalia Indonesia.

Nazir, M. (2013). Metode Penelitian. Bogor: Ghalia Indonesia.

Pramukti, N. (2014). Layanan Perpustakaan Prima di Era Generasi Digital (Digital Natives) :Inspirasi, Transformasi dan Inovasi. Jurnal Fppti, vol 3 no 2.

Pujiriyanto. (2005). Desain Grafis Komputer: Teori Grafis Komputer. Yogyakarta, Indonesia: Penerbit ANDI.

Pujasari Supratman. (2018). Penggunaan Media Sosial Oleh Digitak Native. Jurnal Ilmu Komunikasi vol 15 no 1 .

Pendit, P.L. (2013). Digital Native, Literasi Informasi dan Media Digital. [Available from UKSW Repository Perpustakaan Universitas Kristen Satya Wacana Salatiga.

Prensky, M. (September 01, 2001). Digital Natives, Digital Immigrants Part 1. On the Horizon - the Strategic Planning Resource for Education Professionals, 9, 5, 1-6.

Rahmawati, Ratih. (2016). Pengelolaan Arsip Statis Di Arsip Universitas Gadjah Mada: Yogyakarta. 
Diakses dari Universitas Gadjah Mada repository.ugm.ac.Id/index.

Selwyn, Neil. (n.d.). The digital native: myth and reality. Selwyn, Neil (2009) the Digital Native: Myth and Reality. Aslib Proceedings, 61 (4). Pp. 364-379. Issn 0001-253x.

Sugiyono. (2012). Metode Penelitian Kuantitatif Kualitatif dan R\&D. Bandung, Indonesia: Alfabeta.

Society of American Archivists (2018). In Glossary of Archival and Records Terminology. Retrieved from https://www2.archivists.org/glossary/terms/a/archives.

Virginia, A. (2017). Pergeseran Budaya Komunikasi pada Era Media Baru: Studi Kasus Penggunaan Facebook oleh Digital Natives. Jurnal Komunikasi Indonesia, 1, 2, 77.

To cite this document:

Muhammad, R.U., Anwary, A. (2019). Archieve media promotion for collective memory safety on digital natives generations. Record and Library Journal, 5(1), 50 - 61. 